\title{
Active Teaching-Learning Strategies for Family Medicine Preceptors in the EURACT
}

\section{Estratégias Didáticas Ativas de Ensino-Aprendizagem para Preceptores de Medicina de Família e Comunidade no EURACT}

\author{
Bárbara Cristina Barreiros ${ }^{I}$ (iD \\ Margarita Silva Diercks ${ }^{I I}$ (i) \\ Maríndia Biff ${ }^{I I I}(\mathbb{D}$ \\ Ananyr Porto Fajardo ${ }^{I I}$ iD
}

\section{KEYWORDS}

- Health Technology Assessment.

- Professional Training.

- Preceptorship.

- Medical Education.

- Family Practice.

- Public Health.

III Universidade Federal da Fronteira Sul, Passo Fundo, Rio Grande do Sul, Brazil. 


\section{PALAVRAS-CHAVE}

- Avaliação de Tecnologias em Saúde.

- Formação Profissional.

- Preceptoria.

- Educação Médica.

- Medicina de Família e Comunidade.

- Saúde Pública.

\section{RESUMO}

Introdução: O médico de família e comunidade (MFC) tem como campo de atuação a atenção primária à saúde, sendo preparado para atuar no cuidado das pessoas, famílias e comunidade. Sua formação ideal deve acontecer em Programas de Residência Médica em Medicina de Família e Comunidade (PRMMFC), campo de ensino em serviço em que um preceptor, também MFC, acompanha o residente. O preceptor pedagogicamente bem formado consegue atuar no processo de aprendizado do residente para que desenvolva as competências necessárias para seu futuro exercício profissional. As metodologias ativas de aprendizagem (MAP) ancoram-se na pedagogia crítica e trabalham com problemas para o desenvolvimento dos processos de ensino-aprendizagem. Partem da prática e, a partir dela, buscam a teoria; com isso, preparam o residente para tomar consciência de seu mundo e atuar na transformação dele. As MAP são concretizadas nos processos pedagógicos pelas estratégias didáticas ativas de ensino-aprendizagem, recursos pedagógicos efetivos utilizados pelos preceptores no cotidiano de formação do residente. São divididas em dois grupos: dinâmicas ativas de ensino-aprendizagem e ações para o ensino ativo. Este artigo relata os efeitos de um curso de formação para preceptores de MFC no uso de dinâmicas ativas de ensino e ações para o ensino ativo no processo de preceptoria em PRMMFC. Método: Pesquisa qualitativa, do tipo estudo de caso comparativo mediante o uso de formulário sociodemográfico, entrevista individual semiestruturada e diário de campo. As informações produzidas foram examinadas por análise de discurso, tendo participado dez preceptores de quatro PRMMFC do estado de São Paulo, Brasil (metade realizou o curso Leonardo EURACT nível 1 e metade não). Resultados: Os preceptores que fizeram o curso demonstraram maior conhecimento e uso de utilização de estratégias didáticas de aprendizagem, especificamente dinâmicas ativas de ensino-aprendizagem e ações para o ensino ativo. Conclusões: Foi possível perceber que a tecnologia de ensino Leonardo EURACT nível 1 modifica a prática de ensino dos preceptores que o cursaram, pois demonstram maior uso e domínio das ferramentas na sua prática pedagógica. Além disso, o curso possibilita maior compreensão das dinâmicas e ações apresentadas e, assim, promove o aprendizado dos residentes de forma crítica e estimulando a autonomia.

Received on 5/5/20

Accepted on 6/20/20

\section{INTRODUCTION}

With the creation of the Brazilian Unified Health System (SUS, Sistema Unico de Saúde) and the implementation and expansion of the Family Health Strategy (FHS), the Primary Health Care (PHC) needs qualified medical specialists to provide adequate care to individuals. They must be clinically competent and take into account the cultural, socioeconomic and psychological situation of individuals, their families and community. The Family Doctor (FD) is one of these specialists ${ }^{1-3}$.

The medical residency, a postgraduate teaching modality with inservice training, is the gold standard for the training of this professional, being the responsibility of a health institution through the guidance/ supervision of professionals called preceptors ${ }^{4,5}$. In the residency setting, the preceptors facilitate the residents' learning and commit themselves to the assistance of people under their care, and must maintain a professional, technical and ethical conduct ${ }^{6-8}$.

Several authors have defined the characteristics and necessary competencies for the preceptor. Some are teaching knowledge, teaching skills and posture when teaching. They include activities that are necessary in the preceptor's work process, such as regular observation and analysis of the residents' activities, evaluating and offering constant feedback about their skills in practice. Other aspects are also mentioned as important: knowledge of learning theories and learning styles, as well as the specifics of adult learning. All of this allows the preceptors to determine the status of the teaching-learning process in which the residents are, outlining goals for their training as FDs ${ }^{9,10}$.
It is suggested that the teaching of Family and Community Medicine be supported by active learning methodologies (ALM), therefore focused on the resident and on the problematizing of social and health demands of an individual or population. In turn, ALMs are anchored in critical pedagogy and work with everyday problems for the development of teaching-learning processes. To problematize means being able to respond to the intrinsic conflict that the problem brings ${ }^{11}$. They start from practice and seek the theory; thus, they prepare students to become aware of their world and work towards its transformation ${ }^{12,13}$. Additionally, they question how much the experience changed the understanding, apprehension, attitudes and behavior of both the student and the teacher ${ }^{14}$.

ALMs are materialized in the pedagogical processes through the Active Teaching-Learning Strategies, which are effective pedagogical resources used by the preceptors in the resident's daily training. These strategies can be divided into two groups: Active Teaching-Learning Dynamics, which are teaching techniques, and Active Teaching Actions, which include postures taken by the facilitator to enhance active teaching ${ }^{15}$.

Chart 1 shows examples of the two groups of Active TeachingLearning Strategies ${ }^{15-17}$.

Several educational proposals based on Active Learning Methodologies (ALMs) have been made available in the country for the preceptors of the Medical Residency Programs in Family Medicine (MRPFM). Since 2011, the Brazilian Society of Family and Community Medicine has brought to Brazil the Leonardo EURACT Course for Trainers in Family Medicine, from the European Academy of Teachers of

REVISTA BRASILEIRA DE EDUCAÇÃO MÉDICA

2 44 (3) : e102; 2020 


\begin{tabular}{|c|c|}
\hline \multicolumn{2}{|c|}{$\begin{array}{c}\text { Chart 1 } \\
\text { Active Teaching-Learning Strategies }\end{array}$} \\
\hline Active Teaching-Learning Dynamics & Active Teaching Actions \\
\hline $\begin{array}{l}\text { Buzz Groups/Brainstorming } \\
\text { Guiding Questions / Queries }\end{array}$ & $\begin{array}{l}\text { Use of adult learning theory } \\
\text { principles to continuously challenge } \\
\text { and engage students }\end{array}$ \\
\hline Debates & Promotion of effective group work \\
\hline $\begin{array}{l}\text { Fishbowl } \\
\text { Role playing }\end{array}$ & $\begin{array}{l}\text { Teaching according to the resident's } \\
\text { different learning styles }\end{array}$ \\
\hline Student Presentations & $\begin{array}{l}\text { Practice observation on site or in } \\
\text { video }\end{array}$ \\
\hline \multicolumn{2}{|l|}{ Games } \\
\hline $\begin{array}{l}\text { Case studies } \\
\text { Formulation of Questions } \\
\text { Group work }\end{array}$ & $\begin{array}{l}\text { Direct assistance to students for } \\
\text { their learning and planning their } \\
\text { teaching with academic and career } \\
\text { counseling (mentoring). }\end{array}$ \\
\hline Direct observation. & \\
\hline
\end{tabular}

Source: Systematized based on Gleason BL et al, 2011, Davis BG, 2009 and Fink LD, 1999. $(15,16$ and 17)

Family Medicine (EURACT). Between 2011 and 2018, fifteen editions of the course - level 1 - were held in Brazil, having consolidated a significant group of preceptors with pedagogical training.

The Leonardo EURACT Project, which started in Europe in 2004, aims at structuring and developing a continuing education course for preceptors / trainers in General and Family Medicine, or Family and Community Medicine, as this specialty is called in Brazil. The theoreticalmethodological framework of Leonardo EURACT courses is supported by active learning methodologies, more specifically in the active teachinglearning strategies, aiming at problematizing the preceptor's practice when supervising the professional development of the future FD. Throughout the course, preceptors learn a range of dynamics and active teachinglearning actions that can be used in the educational process with residents. It is a comprehensive program and includes courses that adequately meet the different educational needs of Family Medicine trainers ${ }^{18,19}$.

During the three-day course, 36 preceptors from different MRPFM in Brazil and six facilitators lead discussions on the process of training the FD resident. The Leonardo EURACT Level 1 Course addresses the following topics: What is a Good Trainer/Preceptor, Education and Assessment Theory, Learning Styles and Personal Training Plan, Teaching Methods and Feedback in Practice, Role playing in Medical Education, and How to Develop a Teaching Plan ${ }^{20}$.

In the Leonardo EURACT Level 1 course, preceptors are introduced and encouraged to experience learning dynamics: the sharing of ideas in pairs or groups (brainstorming, buzz group), working in small groups, role playing, case discussion, fishbowl, direct observation, and video use in teaching. Moreover, several active teaching actions are critically experienced by the preceptors, such as: feedback, personal development plan, use of learning styles in teaching with the application of learning styles inventory, and adult learning theories for the teaching of residents.

This study aimed to evaluate Active Teaching-Learning Strategies in the pedagogical training of Family and Community Medicine preceptors offered by the Leonardo EURACT level 1 preceptor training course, as well as to compare the differences in preceptorship with those who did not take this course.

\section{METHODOLOGY}

This is a qualitative comparative case study that describes and analyzes the contexts, associations, and perceptions of a certain episode ${ }^{21}$. The initial study population consisted of 37 preceptors from four MRPFM from the state of São Paulo, Brazil who did or did not take the Leonardo EURACT Level 1 Course. All of them were contacted by electronic message (WhatsApp) and e-mail; twenty did not answer, three did not meet the study inclusion criteria, and four, despite initially accepting the invitation, did not respond to the Consent Form (CF) or did not provide a date / time for their participation in the research. Therefore, the number of participants consisted of ten preceptors, five in the group of those who took the Leonardo EURACT Level 1 Course and five who did not participate in the training course.

The participants who took the course met the inclusion criteria, namely: conclusion of the Leonardo EURACT Course Level 1 more than 6 months previous to the inquiry; supervision of residents during the data collection period; experience of at least six months as a preceptor; and willingness to participate in the study. The preceptors who did not take the course had to meet the following inclusion criteria: supervision of residents during the data collection period; experience of at least six months as a preceptor; and willingness to participate in the study.

Although the number of participants in the research was below expectations, the collected data showed a deeper understanding of the proposed topic, a wide range of empirical and analytical categories, as well as diversity in the process of understanding the perceptions brought by the preceptors of the two assessed groups ${ }^{22}$.

Data were collected between July and October 2018 from three sources: sociodemographic form, filled out after accepting and signing the CF; semi-structured individual interview, lasting approximately 50 minutes, conducted via Skype; and field diary, prepared by the main researcher based on the impressions during the interviews.

The participants were identified by the letter "e", followed by a number assigned according to the order of interviews of each group. Two groups were created to compare the effects of the assessed technology: Group 1 (G1) consisted of participants who took the Leonardo EURACT Level 1 Course (identified as e1 to e5), and Group 2 (G2) consisted of those who did not take it (identified as e6 to e10).

The data related to the sociodemographic questionnaire were tabulated and analyzed according to their frequency. The interviews were transcribed in full and were interpreted according to the content analysis technique, which leads to the understanding of the topics through the meaning of the speeches and their implications. The field diary provided support to the main researcher throughout all stages of the research, bringing observations and conclusions of behaviors, that is, aspects that complement those observed in the other assessment tools ${ }^{21}$.

The study was approved by the Research Ethics Committee of Grupo Hospitalar Conceição via Plataforma Brasil, under Opinion N. 2,659,588 of May 17, 2018. The focus of this article is one of the identified analysis categories, the Active Teaching Strategies for Teaching and Learning in the daily training of Family Medicine (FM) residents.

REVISTA BRASILEIRA DE EDUCAÇÃO MÉDICA

3 44(3) : e102; 2020 


\begin{tabular}{|c|c|c|c|c|c|c|}
\hline \multicolumn{7}{|c|}{ Chart 2} \\
\hline Interviewees / Group & Title & $\begin{array}{l}\text { Preceptor } \\
\text { training course }\end{array}$ & $\begin{array}{c}\text { Time working as } \\
\text { a preceptor }\end{array}$ & $\begin{array}{l}\text { Workload dedicated to } \\
\text { preceptorship }\end{array}$ & $\begin{array}{l}\text { Number of residents } \\
\text { under their supervision }\end{array}$ & $\begin{array}{l}\text { Preceptorship } \\
\text { incentive grant }\end{array}$ \\
\hline E1-G1 & $\begin{array}{l}\text { MR and } \\
\text { SPEC }\end{array}$ & $\begin{array}{l}\text { E-1, E-A and } \\
\text { CPHAOC }\end{array}$ & 3 semesters & $40 \mathrm{~h}$ & 5 residents & no \\
\hline E2-G1 & MR & E-1 e CPHAOC & 1 semester & $40 \mathrm{~h}$ & 5 residents & no \\
\hline E3-G1 & $\begin{array}{l}\text { MR and } \\
\text { SPEC }\end{array}$ & $\begin{array}{l}\text { E-1, ABEM, } \\
\text { FAIMER }\end{array}$ & $>10$ semesters & $30 \mathrm{~h}$ & 5 residents & no \\
\hline E4-G1 & $\begin{array}{l}\text { MR and } \\
\text { SPEC }\end{array}$ & E-1 & $>10$ semesters & $40 \mathrm{~h}$ & 5 residents & no \\
\hline E5-G1 & MR & E-1 e CPHAOC & $>10$ semesters & $40 \mathrm{~h}$ & 1 resident & no \\
\hline E6-G2 & MR & & 1 semester & $40 \mathrm{~h}$ & 5 residents & yes \\
\hline E7-G2 & $\begin{array}{l}\text { MR and } \\
\text { SPEC }\end{array}$ & UNASUS & 1 semester & $20 \mathrm{~h}$ & 4 residents & yes \\
\hline E8-G2 & $\mathrm{MR}$ & СРНАОС & $>10$ semesters & $40 \mathrm{~h}$ & 4 residents & no \\
\hline E9-G2 & $\begin{array}{l}\text { MR and } \\
\text { SPEC }\end{array}$ & СРНАОС & 5 semesters & $40 \mathrm{~h}$ & 5 residents & no \\
\hline E10-G2 & MR & & $>10$ semesters & $20 \mathrm{~h}$ & 2 residents & no \\
\hline
\end{tabular}

Source: Systematized based on data extracted from the sociodemographic questionnaires. MR = Medical Residency in Family and Community Medicine, SPEC = Specialization, E- 1 = Leonardo EURACT Level 1, E-A = Leonardo EURACT Assessment, CPHAOC = Preceptorship Training at Hospital Alemão Oswaldo Cruz, UNASUS - FD Preceptorship Course SBMFC , ABEM = Preceptorship Course of the Brazilian Association of Medical Education, FAIMER = Specialization in the health education area

\section{RESULTS}

Chart 2 presents the data collected by means of the sociodemographic questionnaire. The collected information shows that the preceptors of both groups attended residency in FM, but none of them attended stricto sensu postgraduate courses. Four preceptors from G1 had taken another training course in preceptorship in addition to Leonardo EURACT Level 1 Course, while in G2 three preceptors took only one course, and two took none.

Regarding the time dedicated to preceptorship, most participants in both groups dedicate between 31 and 40 hours a week to this activity. However, in relation to the professional fees for their work, only two G2 preceptors receive them.

To demonstrate the use of Active Teaching-Learning Strategies, the results of this research were divided into Active Teaching-Learning Dynamics and Active Teaching Actions.

\section{Active Teaching-Learning Dynamics}

Chart 3 shows the Active Teaching-Learning Dynamics that were mentioned by the preceptors in each group.

When analyzing the knowledge and use of active didactics by the interviewees, it was identified that seven types were mentioned in G1, while three were mentioned in G2.

Next, the active teaching didactics applied in Leonardo EURACT Level 1 is analyzed, as well as its use when comparing the two groups.

Regarding the use of direct observation in the preceptorship practice, the G1 and G2 participants reported the following:

Shadowing: they follow my consultation and we discuss mainly aspects of communication skills in class. (e1)

I try to provide the appointment side by side with them, so quite often I see what we need, using the Calgary [Calgary Cambridge]. (e2)

I usually like to watch because I also discuss their approach. (e7)

There is the Consultation Observation Tool, which it is like the shadowing. You watch the visit without interfering in anything, and then give the feedback later. (e6)

G2 preceptors reported using case discussion as follows:

So, first we go back, review the points of disagreement, then

\begin{tabular}{|c|c|}
\hline Active Teaching-Learnin & $\begin{array}{l}\text { Chart } 3 \\
\text { Dynamics mentioned by the preceptors. }\end{array}$ \\
\hline Research Group & $\begin{array}{l}\text { Active Teaching-Learning Dynamics } \\
\text { mentioned by the preceptors }\end{array}$ \\
\hline & $\begin{array}{l}\text { Direct observation: shadowing, inverted } \\
\text { shadowing, side by side }\end{array}$ \\
\hline & Brainstorm \\
\hline Group 1 (with Leonardo & Role playing \\
\hline EURACT Level 1) & Buzz group \\
\hline & Case discussion \\
\hline & Debates: article \\
\hline & Analysis of video: video \\
\hline & Direct observation: side by side \\
\hline Group 2 (without Leonardo & \\
\hline & Case discussion, one-minute preceptor \\
\hline
\end{tabular}

Source: Systematized based on data extracted from the interviews. 
the points of agreement, whatever else closes the subject, then we summarize everything and then decide about the conduct together. (e7)

We discuss, they say everything, and I point to something, I ask them to give me the hypotheses, what they thought about doing and I do, too, I point little by little. (e8)

I do the 'One-minute preceptor', which is a little bit like the case discussion idea. (e10)

G1 preceptors report conducting the case discussion as follows:

They tell me all about the case, I do not interfere, we start with: What is your diagnosis? What is your conduct? What is your evaluation? What would you do with this patient? And why did you make these assessments, and will you follow this plan? They answer. Then I give them the feedback on why I think this or that, and as for the plan, it is the same thing. (e1)

Nothing is given for free ... they expose the case, the entire clinical history, physical examination, conduct ... by asking questions, they are actively participating, building the path. (e2)

G1 preceptors point out several characteristics of role playing in the application of teaching in health:

So, I decided to do the role playing mainly because I saw that, in some discussions, there were some pending points, and with the role playing I can handle those points that are more difficult to work with the residents. Learning to expose themselves, to communicate, and, above all, learning to deal with situations that, perhaps, they are not dealing with in their daily lives. I think that role playing is a good technique. (e2)

The role playing caught my attention during the EURACT, it was one of the things that interested me a lot. [...] I had an extremely difficult team, an extremely poor family discussion. At one point, I said: Let's do something I learned? It is a role playing. (e5)

G2 preceptors speak about their use of dramatization in their practice:

It is something that I do not have much experience with. I never saw it much and, performed it even less. I would not feel capable of doing it. Perhaps even because I have no experience, it would be very complicated. (e8)

Very little, I have used it, mainly, in this initial phase of the two minutes of consultation, and we end up doing a role play. Let's pretend here I am the patient; you will bring me the questions and I will tell you. (e10)

\section{Active Teaching Actions}

Chart 4 shows the Active Teaching Actions mentioned by the G1 and G2 preceptors.

When analyzing the knowledge and use of active education actions, G1 preceptors mentioned four types, while G2 preceptors mentioned only one. G1 preceptors seem to use a greater variety of teaching actions, especially those based on the student's (resident's) full knowledge, which facilitates and qualifies the pedagogical process and its result, the learning.

We will now analyze the active teaching actions applied in Leonardo EURACT Level 1, based on the comparison of their use in the two groups.

The use of feedback is reported as follows by G1:

I can do it. I have been able to do a weekly feedback. It has been very positive, but feedback is something you learn by doing it. There is a whole question like this: each resident has their own profile and has their own way of understanding what you are presenting. (e2)

Now, technically, I think the fact that, perhaps, having had trained the feedback, I think it was important. (e3)

I think what really changed was the feedback, really. Giving feedback. There, at EURACT. (e4)

And I use the same feedback technique. Always point out more positive things, initially. And I see that the residents, mainly, are much in need of a compliment, of the positive points even for them. (e5)

Among the G2 preceptors, the report on the use of feedback was as follows:

Thus, for the preceptorship I read something and stuff, and then, there is always this question that the feedback should not be aggressive and so forth, always having the positive points too, so I think it has been going on like this, I think there have been no big questions. (e6)

[...] I always try to give feedback on that consultation, but it's more like a discussion within the discussion, so it's more a thing of the moment, faster. "Look, this thing you did was not so good. That what you said to the patient, sometimes, they might not feel well'. So, it's more of a guidance than giving feedback. (e8)

Quite often, it does not work, nowhere near it. I do it, in more critical situations, I realize that I have a huge difficulty with this type of report, speaking more sincerely. I have difficulty with that. So, I feel like I avoid it, I do not do it as much as I should. (e9)

The use of tools for the knowledge of Learning Styles was demonstrated as follows by the G1preceptors:

\begin{tabular}{|c|c|}
\hline Active Teaching & $\begin{array}{l}\text { Chart } 4 \\
\text { ctions mentioned by the preceptors }\end{array}$ \\
\hline Research group & $\begin{array}{l}\text { Active Teaching Actions mentioned by the } \\
\text { preceptors. }\end{array}$ \\
\hline & Adaptation to learning styles: Kolb and VARK \\
\hline Group 1 (with Leonardo & Reflection: portfolio \\
\hline EURACT Level 1) & Preceptor-resident communication: feedback \\
\hline & Personal Development Plan \\
\hline $\begin{array}{l}\text { Group } 2 \text { (without Leonardo } \\
\text { EURACT Level 1) }\end{array}$ & Preceptor-resident communication: feedback \\
\hline
\end{tabular}

Source: Systematized based on data extracted from the interviews.

\footnotetext{
$5 \mid$\begin{tabular}{l|l} 
REVISTA BRASILEIRA DE EDUCAÇÃO MÉDICA \\
\hline 44 (3) : e102; 2020
\end{tabular}
} 
To understand how the resident learns is, therefore, to use several different teaching tools. So, I analyze what the residents do with Kolb and then I think of ways to better teach the content to them. (e2)

If I do not make them get their hands on, they will not learn, no way. And one is much more introspective, so they use the portfolio a lot more and listen and discuss than doing it. The other one likes to read, study, receive material, and so forth. (e1)

The G2 preceptors report the following about learning styles:

But I think this is very incipient, I cannot say that I do it in a very structured way, it's a more intuitive thing. And that is it, my comment with the Nurse and the other Doctor saying "look, this guy, he's not going to go like this, he's going to go in a totally different way", and we try to find another way. (e10)

G1 preceptors report on the use of the Personal Development Plan (PDP):

We are able to identify failures, see interventions on top of those failures, and we can identify needs to be acquired. [...] They set up [the PDP] and bring it to me, we start with one of them and add to it. (e1)

Yes, I set it up. I tried to mentor them and guide, sit, talk, through the feedback, they bring some things that were quite useful for the creation of their PDP. (e2)

G2 preceptors report on the use of the PDP as follows:

Yes, I do it [...] I have a little folder of duties, in relation to study, procedures. Then we add, for instance: They are inserting an IUD. Next time, I won't say anything, I'll just be by their side. I make the plan in this sense. (e9)

\section{DISCUSSION}

Training courses improve the ability of FDs to perform their role in the teaching scenario, and there must be a continuous formative assessment to maintain the pedagogical development. There is evidence that these courses have an impact on teaching practice, and they show signs that they also modify the students' learning and performance ${ }^{24}$. The training increases the preceptor's focus on the students, thus qualifying their learning: the preceptor's training also qualifies the student's training ${ }^{25}$.

The analysis of the sociodemographic data shows that G1 preceptors took more training courses, both in number and diversity, than G2 preceptors. The diversity of the use of active dynamics improves the pedagogical process and, thus, can make it more effective. Taking training courses, however, is not connected to remuneration for the preceptorship activity.

Some authors define the trainer's pedagogical competences, specifying knowledge and skills in teaching, as well as their attitude when teaching. Boendermaker et al. (2000) and Vernooij-Dassen et al. (2000) highlight the regular observation and analysis of residents' activities, constant evaluation and feedback on their skills, application of adult learning knowledge, learning theories and learning styles. These actions allow the preceptor to determine the status of the residents' teaching- learning process, outlining strategies for their training as $\mathrm{FDs}^{9,10}$.

In this study, when we analyze the reported use of active teachinglearning strategies, we can see the difference between the G1 and G2 groups, which, in addition to the number of dynamics and actions used, also show differences in the types of strategies used. G1 preceptors inform the use of a greater variety of teaching strategies, especially those that draw on previous knowledge, generate reflection and influence the acquisition of skills and attitudes by the residents. G2 preceptors, even when indicating the use of such strategies, mention less variety, which can lead to a less effective resident's teaching-learning process.

When we analyze the application of active teaching-learning strategies, we see a difference between the dynamics and actions used in each research group. We will analyze each of the strategies used and the comparison between the groups.

As it assesses skills, attitudes and knowledge, the direct observation should be widely used in the FD preceptorship process to monitor and evaluate the gain in skills to be acquired in the resident's practice ${ }^{26}$.

Regarding the direct observation, both G1 and G2 preceptors mention its use. Preceptors from both groups use Direct Observation in their daily practice, as well as assessment tools for this dynamic, such as Calgary Cambridge and the Communication Observation Tool ${ }^{23,27}$.

Case discussion is a dynamic widely used by preceptors during undergraduate, postgraduate medical course, and even during the physician's clinical practice. The importance of discussing clinical cases in medical education resides in connecting basic science and the real problems of the medical practice, being an important medical learning strategy used during professional training ${ }^{28}$. It requires from the preceptor the technical knowledge of the dynamics and a teaching facilitator's attitude.

The study showed that the process also occurs in FD residency courses, appearing as a dynamic used in both groups. It was possible, however, to observe that G1 preceptors focus the case discussion on the knowledge brought on by the residents, presenting a teaching facilitator attitude, which prioritizes the resident's autonomy over the case, problematizing the teaching and, thus, showing the focus on the active teaching methodologies.

Dramatization or role playing is a teaching dynamic that allows participants to take on a role in a specific situation, imagining that they are someone else or themselves. It aims to achieve the educational objectives specified for each situation, always under the guidance of a preceptor, followed by a discussion, which is an integral part of the process ${ }^{29}$.

The G1 interviewees demonstrate the daily use of this dynamic, pointing out that it can be used in different spaces and situations and, therefore, it is an effective practice of preceptorship. The G2 respondents, however, use this dynamic less often and point out the main barriers to its use.

The feedback regulates the teaching-learning process by continuously providing information so that students can realize how distant or close they are from the desired goals ${ }^{30}$. It is, therefore, an Active Teaching Action that helps in the learning process review, pointing out gaps and agreeing on objectives, methods and results between the preceptor and the resident.

The G1 preceptors indicate that it is an important action for their pedagogical practice and that the Leonardo EURACT Level 1 Course provided practical training. The G2 preceptors show that the action is 
applied, but the preceptors' speech is not as assertive regarding the use of the technique itself and its effectiveness. The recognition of learning styles has educational effects on the teaching process for both students and teachers ${ }^{31}$. It is important to seek knowledge of the learning styles and their use in the teaching strategy of students through the application of inventories/questionnaires such as the one by Kolb or VARK ${ }^{26,32}$. Kolb refers to the inventory of learning styles developed by David Kolb and which, after being filled out, defines the student's preferred learning style $^{33}$. In turn, VARK, an acronym for V-Visual, A-Auditory, R-Reading and $\mathrm{K}$ - Kinestesic, is a questionnaire developed at Lincoln University that provides information on the best way to absorb information and generates a stimulus for reflection and change in their teachers' teaching methods ${ }^{34}$.

Kolb is introduced at the Leonardo EURACT Level 1 Course and the G1 preceptors show that they understand and apply inventories as a teaching action. G2 preceptors perceive the different learning styles, but are unable to apply the technique and, therefore, do not use this tool in the teaching process.

The autonomy over their own learning needs contributes to the intellectual growth and personal development necessary for health professionals. The agreement on learning goals based on the teaching needs, both those desired by the student and the gaps identified by the teacher, is a challenge ${ }^{35}$. The Personal Development Plan (PDP) is another Active Education Action and materializes an action plan focused on the development of the learner's teaching process, based on the subject's reflection and on the assistance, facilitation and mentoring of their preceptor, aiming to achieve the skills of a FD.

G1 preceptors use the PDP in the preceptorship process, being facilitators in the construction of a plan that reinforces the resident's autonomy gain, in learning to learn. In turn, G2 preceptors showed no experience in using the PDP and, sometimes, there is a misunderstanding of the concept (PDP is not a checklist), but they assess the need for including this action in the preceptorship process.

\section{FINAL REMARKS}

This study had limitations regarding the number of participants. During the research, from the design of the project to the data collection phase, there were many changes in the Medical Residency Program scenario in the state of São Paulo. Among them, the migration of preceptors to other MRPFMs and even to private services decreased the number of participants in this study. Additionally, the lack of availability of the preceptors' time limited their acceptance in participating in this research. In spite of that, for being a qualitative research and because there was a saturation of the collected information, the number of participants does not lessen the importance of the study, and further studies on the subject should be carried out in order to reinforce the information raised here.

Based on what was demonstrated in the Results and Discussion sections, regarding the Didactic Teaching-Learning Strategies, the Leonardo EURACT Level 1 Course showed that it increased their number, brought diversity, improved the pedagogical process and made it more effective, in addition to qualifying the practical knowledge of the active learning strategies in the daily life of preceptors, in comparison with preceptors who did not participate in the course. This can be corroborated by Schofield and Hasler, who in 1984 emphasized the importance of teaching strategies used in preceptors' practice. Knowledge and the effective use of these strategies are considered essential for the preceptorship process ${ }^{36}$.

This study showed that the preceptors who took the Leonardo EURACT Level 1 Course and learned a wide variety of Active TeachingLearning Dynamics and Active Teaching Actions feel adequate for their use, qualifying the teaching of FM residents, unlike the preceptors who did not take the course. It was verified that the Leonardo EURACT Level 1 Course, which has as a pedagogical reference the active learning methodologies to approach the preceptorship process, does it so mainly by problematizing the trainer's practice, through content approach and the practical experience of the active dynamics and actions of the teachinglearning process.

This study showed that the Leonardo EURACT Level 1 Course for FM trainers has positive effects on the participants' preceptorship process, since they incorporate active teaching strategies that qualify their skills and attitudes as trainers, making them professionals with a broader set of competencies necessary for the development of the preceptorship process.

The care when integrating teaching and service is important in the organization of Medical Residency Programs to provide protected spaces for teaching. When creating new pedagogical offers, it is necessary to keep the focus on the acquisition of skills for the preceptor, paying attention to the applied teaching methodology, as the best way to teach Active Teaching-Learning Methodologies is to experience them, while using them to qualify and make the teaching effective and active.

\section{ACKNOWLEDGMENT}

The authors would like to thank the Postgraduate Program in Health Technology Assessment for SUS of Grupo Hospitalar Conceição (GHC) for the support in all stages of research development, from the idealization of the project to the publication of the article in this journal.

\section{REFERENCES}

1. Lopes JMC, Dias LC. Princípios da Medicina de Familia e Comunidade. In: Gusso G, Lopes JMC, Dias LC.Tratado de Medicina de Família e Comunidade: princípios, formação e prática. 2a ed. Porto Alegre: Artmed; 2019. p. 1-11.

2. BRASIL. Constituição da República Federativa do Brasil de 1988. Brasília; 1988 [acesso em 28 jan 2018]. Disponível em: http://www. planalto.gov.br/ccivil_03/Constituicao/Constituicao.htm.

3. Allen J, Gay B, Crebolder H, Heyrman J, Svab I, Ram P. A definição europeia da Medicina Geral e Familiar. Rev Port Clin Geral. 2005 (21):511-6 [28 jan 2019.] Disponível em: https://www.rpmgf.pt/ojs/ index.php/rpmgf/article/view/10170/9906

4. Michel JLM, Oliveira RAB de, Nunes $M$ do PT. A residência médica no Brasil. Resid Méd (Brasília). 2011;7:2-12. [28 fev 2019.] Disponível em: https://abem-educmed.org.br/wp-content/ uploads/2016/06/CadernosABEM_Vol09.pdf.

5. BRASIL. Lei $\mathrm{n}^{\circ}$ 6.932, de 7 de julho de 1981. Brasília; 1981. [28 jan 2018.] Disponível em: http://www.planalto.gov.br/ccivil_03/LEIS/ L6932.htm.

6. Botti SH de O, Rego S. Preceptor, supervisor, tutor e mentor: quais são seus papéis? Rev Bras Educ Med. 2008;32(3):363-73. [30 jan 2018.] Disponível em: http://www.scielo.br/pdf/rbem/v32n3/v32n3a11.pdf.

7. Monteiro D, Leher E, Ribeiro V. Da educação continuada à educação

7 REVISTA BRASILEIRA DE EDUCAÇÃo MÉDICA

7 44 (3) : e102; 2020 
permanente. In: Ribeiro VMB, organizador. Formação pedagógica de preceptores do ensino em saúde: a construção do Modelo de formação pedagógica para preceptores de internato médico. Juiz de Fora: Editora UFJF; 2011. p. 13-22. [30 jan 2018.] Disponível em: https://www. researchgate.net/profile/Sergio_Rego/publication/313332486_As_ identidades_do_preceptor_seu_papel_na_formacao_moral_e_etica/ links/5895ecd5a6fdcc32dbd98ble/As-identidades-do-preceptor-seupapel-na-formacao-moral-e-etica.pdf.

8. Dubar C. Formação dos médicos generalistas: transmissão e construção dos saberes profissionais. In: Ribeiro VMB, organizador. Formação pedagógica de preceptores do ensino da saúde. Juiz de fora: Editora UFJF; 2011. p. 23-8. [30 jan 2018.] Disponível em: https://www. researchgate.net/profile/Sergio_Rego/publication/313332486_As_ identidades_do_preceptor_seu_papel_na_formacao_moral_e_etica/ links/5895ecd5a6fdcc32dbd98b1e/As-identidades-do-preceptor-seupapel-na-formacao-moral-e-etica.pdf.

9. Boendermaker PM, Schuling J,Meyboom-de Jong B, Zwierstra RP and Metz JCM. What are the characteristics of the competent general practitioner trainer ? Fam Pract. 2000;17(6):547-53. [25 dez 2018] Disponível em: https://sci-hub.tw/10.1093/fampra/17.6.547.

10. Vernooij-Dassen M, Ram PM, Brenninkmeijer WJM, Franssen LJE, Bottema BJAM, Van Der Vleuten C, et al. Quality assessment in general practice trainers. Med Educ. 2000;34:1001-6. [25 dez 2018.] Disponível em: https://onlinelibrary.wiley.com/doi/full/10.1111/ j.1365-2923.2000.00662.x?sid=nlm\%3Apubmed.

11. Marin MJS, Lima EFG, Paviotti AB, Matsuyama DT, Silva LKD da, Gonzalez C, et al. Aspectos das fortalezas e fragilidades no uso de metodologias ativas de aprendizagem. Rev Bras Educ Med. 2010;34(1):13-20. [28 jan 2018.] Disponível em: http://www.scielo.br/ pdf/rbem/v34n1/a03v34n1.pdf.

12. Abreu JRP. Contexto atual do ensino médico: metodologias tradicionais e ativas - necessidades pedagógicas dos professores e da estrutura das escolas [dissertação]. Porto Alegre: Universidade Federal do Rio Grande do Sul; 2009. Disponível em: http://www.lume. ufrgs.br/bitstream/handle/10183/18510/000729487.pdf.

13. Berbel NAN. A problematização e a aprendizagem baseada em problemas: diferentes termos ou diferentes caminhos? Interface Comun Saúde e Educ. 1998;2(2):139-54. [30 jan 2018.] Disponível em: http://www.scielo.br/pdf/icse/v2n2/08.

14. Cyrino EG, Toralles-Pereira ML. Trabalhando com estratégias de ensino-aprendizado por descoberta na área da saúde: a problematização e a aprendizagem baseada em problemas. Cad Saúde Pública. 2004;20(3):780-8. [30 jan 2018.] Disponível em: http://www. scielo.br/pdf/csp/v20n3/15.pdf.

15. Gleason BL, Peeters MJ, Resman-Targoff BH, Karr S, McBane S, Kelley $\mathrm{K}$, et al. An active-learning strategies primer for achieving ability-based educational outcomes. Am J Pharm Educ. 2011;75(9):112. [19 jan 219.] Disponível em: https://www.ncbi.nlm.nih.gov/pmc/ articles/PMC3230347/.

16. Davis BG. Tools for teaching. First Edition. San Francisco : JosseyBass Publishers. 1993. [21 jan 2019] Disponível em: https://www.elon. edu/docs/e-web/academics/teaching/Tools\%20For\%20Teaching.pdf

17. Fink LD. A Self-Directed Guide to Designing Courses for Significant Learning. San Francisco: Jossey-Bass, 2003. [20 jan
2019]. Disponível em: https://www.deefinkandassociates.com/ GuidetoCourseDesignAug05.pdf

18. Guldal D, Windak A, Maagaard R, Allen J, Kjaer NK. Educational expectations of GP trainers . A EURACT needs analysis. European Journal of General Practice, 2012; 18: 233-237 [doi: 10.3109/13814788.2012.712958.

19. Allen J, Svab I, Price E, Windak A. Framework for Continuing Educational in General Practice / Family Medicine in Europe (CEDinGP). Cracovia: ZiZ Centrum Edukacji; 2012. 38 p. [30 jan 2019] Disponível em: http://euract.woncaeurope.org/sites/euractdev/files/documents/ publications/official-documents/euractframeworkforcontinuingeducationaldevelopmentoftrainersingeneralpracticeineuropecedingp.pdf.

20. Euract/Wonca. Leonardo Level 1. Prague; 2019. [09 abr 2020] Disponível em: http://leonardoprague2019.cz/program.

21. Minayo MC de S. O desafio do conhecimento: pesquisa qualitativa em saúde. 11a ed. São Paulo: Hucitec; 2008. 407 p.

22. Minayo MC de S. Amostragem e saturação em pesquisa qualitativa: consensos e controvérsias. Rev Pesqui Qual. 2017;5(7):1-12. [19 fev 2019.] Disponível em: http://rpq.revista.sepq.org.br/index.php/rpq/ article/view/82.

23. Levinson W, Lesser CS, Epstein RM. Developing physician communication skills for PCC. Health Aff. 2010;7:1310-8.

24. Mash R, Blitz J, Edwards J, Mowle S, Kingdom U, Mash R. Training of workplace-based clinical trainers in family medicine, South Africa: before-and-after evaluation. African J Prim Heal Care Fam Med. 2018;10(1):1-6.

25. Gibbs G, Coffey N. The impact of training of teachers on their teaching skills, their approach to teaching and the approach to learning of their students. Act Learn High Educ. 2004;5(1):87-100. [25 dez 2018.] Disponível em: http://reforma.fen.uchile.cl/Papers/Teaching Skills Gibbs, Coffey.pdf.

26. Cayer S, St-Hilare S, Boucher G, Bujold N. La supervision directe: perceptions d'ex-résidents en médecine familiale Suzanne. Can Fam Physician. 2001;47:2494-9. [31 dez 2018.] Disponível em: https:// www.ncbi.nlm.nih.gov/pmc/articles/PMC2018478/.

27. Silverman JD, Kurtz SM, Draper J. The Calgary Cambrige approach to communication skills teaching. The set-go method of descriptive feedback. Educ Gen Pr. 1997;8:16-23.

28. Abensur SI, Abensur H, Malheiros MAC, Zatz R, Barros R oledo. Uso da internet como um ambiente para discussão de casos clínicos. Rev Bras Educ Med. 2007;31(3):291-5. [02 jan 2019.] Disponível em: http://www.scielo.br/pdf/rbem/v31n3/12.pdf.

29. Simpson MA. How to use role play in medical teaching. Med Teach. 1985;7(1):75-82. doi: 10.3109/01421598509036794.

30. Borges MC, Miranda CH, Santana RC, Bollela VR. Avaliação formativa e feedback como ferramenta de aprendizado na formação de profissionais da saúde. Med (Ribeirão Preto). 2014;47(3):32431. [13 dez 2018.] Disponível em: http://revista.fmrp.usp.br/2014/ vol47n3/11_Avaliacao-formativa-e-feedback-como-ferramenta-deaprendizado-na-formacao-de-profissionais-da-saude.pdf.

31. Pena AFR, Cavalcante B, Mioni C de C. A Teoria de Kolb : análise dos estilos de aprendizagem no curso de Administração da Fecap. Rev Liceu On-line. 2014;4(6):64-84. [31 dez 2018.] Disponível em: https:// liceu.fecap.br/LICEU_ON-LINE/article/view/1719/974.

$8 \mid$\begin{tabular}{l|l} 
REVISTA BRASILEIRA DE EDUCAÇÃO MÉDICA \\
\hline 44 (3) : e102; 2020
\end{tabular} 
32. Newble DI, Entwistle NJ. Learning styles and approaches: implications for medical education. Med Educ. 1986;20(3):162-75. doi: 10.1111/ j.1365-2923.1986.tb01163.x.

33. Kolb AY, Kolb DA. Learning styles and learning spaces: enhancing experiential learning in higer education. Acad Manag Learn Educ. 2005;4(2):193-212. doi: 10.5465/amle.2005.17268566.

34. Fleming ND. I' $m$ different; not dumb Modes of presentation (V. A. R. K.) in the tertiary classroom in Zelmer,A., (ed.) Research and Development in Higher Education, Proceedings of the 1995 Annual Conference of the Higher Education and Research Development Society of Australasia (HERDSA),HERDSA. 1995;18: 308 - 313

35. Sandars J, Jackson B. Self-authorship theory and medical education: AMEE Guide no 98. Med Teach. 2015;37(6):521-32. doi: 10.3109/0142159X.2015.1013928.

36. Schofield TPC, Hasler JC. Approval of trainers and training practices in the oxford region: criteria. Br Med J. 1984;288:538-40. [25 dez 2018.] Disponível em: https://www.ncbi.nlm.nih.gov/pmc/articles/ PMC1444558/pdf/bmjcred00488-0048.pdf.

\section{AUTHORS' CONTRIBUTION}

B. C. Barreiros was responsible for the study conception, design, data collection and analysis and writing of the manuscript. M.S. Dierks was a co-supervisor and reviewed the final version of the manuscript. M. Biffi collaborated in the data collection and in the writing of the manuscript. A. P. Fajardo was the advisor of the study that originated the article, and was responsible for the study design, performed a review of the data analysis and the writing of the manuscript.

\section{CONFLICTS OF INTEREST}

B. C. Barreiros is a is facilitator and organizer in Brazil of Leonardo EURACT courses for Family Medicine Preceptors. The other authors declare no conflicts of interest.

\section{ADDRESS FOR CORRESPONDENCE}

Bárbara Cristina Barreiros. Rua Mauricio Jacquey, 199, ap. 25, Vila Helena, São Bernardo do Campo, SP, Brasil. CEP: 09635-080.

E-mail: barbaracbarreiros@gmail.com 